\title{
ヒスタミン脳内投与による 鎮痛作用発現について
}

\author{
第 2 報
}

一無麻酔ウサギ歯髄の電気刺激による

視床及び中脳網様体誘発電位に及ぼす

ヒスタミンの影響一

岡山大学歯学部口腔外科学第 1 講座（主任：西嶋克已教授）

岡田郁男

（昭和57年11月26日受稿）

Key words: ヒスタミン, 歯髄刺激, 誘発電位,

モルヒネ, 抗ヒスタミン剤

\section{緒 言}

歯㕼の電気刺激による痛覚の発現に関しては, 既に多くの研究が報告されているが，その大部 分は急性実験における成績である，痛覚の伝導 路に関する電気生理学的研究では, 急性実験で 所期の目的を達し得る場合が多く，特に大脳皮 質に局在する痛覚中枢の探索は，急性実験以外 では困難である。しかし，急性実験で歯髄刺激 を行う場合には，歯鹃以外の部位から多数の求 心性 impulse が上行し，此等が歯髓刺激に由来 する response を修飾している可能性が極めて 大きいと考えられる。この点を考虑して, 著者 は back ground noise の少ない無麻酔条件下に 蒾髄刺激を行い得る慢性実験を企画した。

歯跹を電気刺激した際，その主な求心路とし $\tau, 1$ ) 三叉神経主知覚核 $\rightarrow 反$ 对側視床内側後 腹側核 $\rightarrow$ 大畄皮質第一体性感覚野，2）三叉神 経脊髄路核 $\rightarrow 反$ 对側視床後核群 $\rightarrow$ 大脳皮質第二 体性感賞野へと投射される2つの経路が報告さ れている1! 視床後核群とは内側㮏状体の内側部, 滕状体核，後外側核の一部を含む領域であり， ネコ,サル及びラットなどでは三叉神経の求心 性 impulse が投射している事が報告されている?! 一方，歯䯣刺激後，視床や大脳皮質以外に中脳 網様体でも誘発電位が記録される事が報告され

\section{ている3 ${ }^{3 \sim 4}$.}

Histamine (以下 Hi と略) は静脈内に投与巳 れても，脳一血液関門を通過し難いので5)，そ の中枢神経系に対する直接作用は， systemicな 効果としては多くの場合発現しない。しかし， 体性蔵器における Hi 感受性の低い種属に Hi の大量が投与された際, 鎮痛効果が観察される 事が報告されているが） その作用機序は殆んど 不明のままにとり残されている。著者はマウス 脳内に $\mathrm{Hi}$ を投与した際, 種々な体性知覚神経 刺激による仮性疼痛反応に対して Hi が抑制的 に作用する事を報告している?! 純粋な痛覚を生

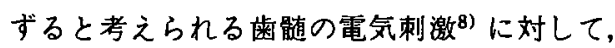
中枢神経系に存在する $\mathrm{Hi}$ が如何なる影響を及 ぼしているのかについて理解するため，視床の 特殊核及び中脳網梯体における誘発電位を指標 として Hi を脳室内に投与し，その効果を検討 した.

\section{実験方法ならびに実験材料}

1. 基礎的事項の検討方法

今回の慢性実験における最大の問題点は，歯 㗙刺激用電極を如何に長時間にわたり使用可能 な状態に維持するのかにあった。この目的には， 刺激電極の植之込みの際使用するセメントとし ては，1）電気的絶縁性の高いセメントである 
事, 及び2）抗破砕力の強い事が必須な条件にな る.また, 手術時の種々な分泌物による電極間の短 絡や絶緑性の低下を可能な限り防止する事が, 高い絶縁性を持続させるためのもう1つの基本 的な条件である。この目的には, 硬化時間の短 いセメントを使用する事が要求される，絶緑性， 抗破砕力及び硬化時間の三つを parameter と して種々な歯科用セメントを予め検討し，それ らの中からポリセット (矢田化学工業K.K.), パイルB（松風陶歯製造K.K.），ユニファスト（而 至陶歯工業K.K.）及びエリートセメント（而至 陶歯工業K.K.）の4種を選び，上記の各項目に ついて検討した。

抗破砕力の測定は, 直径 $5 \mathrm{~mm}$, 長さ $8 \mathrm{~mm}$ の ステンレス製の鋳型にこれらのセメントを注入 し, 硬化させた後温度 $20^{\circ} \mathrm{C}$, 湿度 $100 \%$ の培盖 器に入れて24時間放置した。その後湿度 $100 \%$ のガーゼに包んで table 上に置き，島津製作所 のオートグラフ IS 5000 を用いて, へッドスピ 一ド 1 分間 $1 \mathrm{~mm} の$ 条件で圧迫破研した。 その 際の応力を $\mathrm{kg} / \mathrm{cm}^{2}$ で表示した。

絶縁性の測定には，雄性白色ウサギの大切歯 を歯頸部で切断して $1 \% \mathrm{KOH}$ に 週間浸漬し， 結合組織を完全に除去した後，充分水洗して1 週間風乾させたものを用いた。切歯の切断面に 2 本のネジ電極を植え込み，それにリード線を つなき，接点を種ふなセメントの充分な量で被 覆し, 且つ霜冠部も元の状態に修復し，その後 30日間生理食塩液に浸漬した。 その間電極間抵 抗を 1 日 1 回測定した。各セメントことに前述 の継続雨を 6 本作成し，電極間抵抗は武田理研 万能型測定器 (TR-8651) で測定した。

硬化時間の測定は，厚さ $4 \mathrm{~mm}$, 直径 $5 \mathrm{~mm}$, の円板を被検用セメントで可及的速やかに作成 し，注射針で突き刺しながら針が表面を通過で きなくなるまでの時間（硬化時間）を測定した.

前述の 3 つの要素以外に，硬度の高い飼料を 用いた場合には，刺激電極を損傷する可能性が 予想されたので，飼料の硬度についても検討し た．各社の飼料を無差別に各 100 箇とり出し, モンサント硬度計（荁垣医科工業製）で粉碎強 度を測定した。

2. 記録用及び刺激用慢性電極の装着
体重 $3 \mathrm{~kg}$ 前後の雄性白色ウサギを pentobarbital $(35 \mathrm{mg} / \mathrm{kg})$ 静注により麻酔した後, 脳定 位固定装置（東大脳研式）に固定し, Sawyer らの脳地眓 ${ }^{9)}$ に従って脳波誘導用の単極電極を 中脳網様体 (RF; P: 8.0, L: 3.0, H: -1.0), 視床 VPM 核 (N. ventralis posteromedialis of the thalamus, VPM; P: 4.0, L: 3.0, H:1.0）に stereotaxic に植之込み，別に薬液注入 用カニューレを㑡脳室 (A: 1.0, L: 2.8, H: 6.0)に挿入した。各電極は頭頂部においたソヶ ット（サトーパーツ製，9P）の足にハンタ付 けして、これらをまとめて歯科用セメントで固 定し，慢性電極を装着させた。術後約 1 週間経 過した後, 再び pentobarbital 静脈内麻醉下に 歯髄刺激用のステンレス電極を切歯に植之込ん だ. 上頜の左右の大切歯の歯頸部雪肉を切除し て歯根部の一部を露出させ, 切菌の弯曲を考慮 しながら菌䯣の方向へ向けて細い contra round bar（No. 1/4, Maillefer, Swiss）を用いて注意 哚く歯骮を穿孔させた，先端の $1 \mathrm{~mm}$ を露出さ せたエナメル被覆ステンレス電極を， $1 \mathrm{~mm} の$ 間隔で 1 本の歯に 2 本づつ植え込んだ。そその後， 電極插入部の近くで予め大切菌に植之込んだ小 型のビスにステンレス電極をまいて固定し，リ ード線をハンダ付けした，電極とリード線の接 点ならびに電極の㨂入部位をそれぞれビニール 樹脂盗料で被覆した．塗料が乾燥した後充分な 量のユニファストで更に両部位を被覆した。リ 一ド線は，上唇小帯の付近で口腔粘膜を貫通さ せ，上額骨前面の皮下組織を通過させて頪部の 皮膚に露出させ, 更に脳波記録用ソケットの前 に固定した刺激用ソケット（昭和無線工業製, $6 \mathrm{P})$ まで導いた。刺激用ソケットと記録用ソ ケットとの間は, $1.0 \mathrm{~cm}$ 以上の距離をおき，両 ソケット間の絶緑には充分注意を払った。術後， 1 週間以上経過した時点よ。り，無麻酔で実験を 行った。薬物はすべて生理食塩液に溶解させ, 容量 $20 \mu \mathrm{l}$ の薬液をがイドカニューレを通して, 60 秒に投与時間を一定してゅっくりと㑡脳室内 に注入した。

歯葡の刺激は 3-8 V, 0.1-0.5 $\mathrm{msec}, 2 \mathrm{~Hz}$ の 短形波刺激を 100 回与之, その際, 中脳網梯体及 び視床 VPMで記録される誘発電位を 16 add- 
ress の delay をかけて反応加算解析装置（日本 光電, ATAC 501-20） て加算し，100 msecの時 間幅で oscilloscope 上に display させたものを 撮影し記録した。

\section{3. 使用薬物}

実験に使用した薬物は, histamine dihydrochloride (東京化成), pyrilamine hydrochloride (ICN Laboratories), cimetidine

(Smith Kline \& French Ltd.). morphine(田 辺製薬)，pentazocine (山之内製薬) であり， 括孤内に購入先ないし入手先を記入した。

\section{実験 成}

1. 歯科用セメントの物理的性質

30日間生理食塩液に浸漬した継続菌に㨉入し た 2 本の電極間抵抗值, 各種のセメントで作成 した円板の硬化時間, 抗破碎力は表 1 に一括し て示した、エリートセメントは、絶縁性が極め

表 1 市販歯科用セメントの物理的性質の比較

\begin{tabular}{lccc}
\hline & $\begin{array}{c}\text { 電気抵抗值 } \\
(\mathrm{M} \Omega) \mathrm{n}=6\end{array}$ & $\begin{array}{c}\text { 硬化時間 } \\
(\mathrm{sec}) \mathrm{n}=20\end{array}$ & $\begin{array}{c}\text { 抗破砕力 } \\
\left(\mathrm{kg} / \mathrm{cm}^{2}\right) \mathrm{n}=20\end{array}$ \\
\hline ポリセット & $422 \pm 160$ & $133 \pm 12$ & $688 \pm 58$ \\
パイルB & $550 \pm 96$ & $676 \pm 5$ & $636 \pm 66$ \\
ユニファースト & $595 \pm 106$ & $150 \pm 2$ & $534 \pm 53$ \\
エリートセメント & $0.53 \pm 0.10$ & $430 \pm 5$ & $591 \pm 83$ \\
\hline
\end{tabular}

で被覆した後フフジバーニッシュ（而至陶歯工 業）で coating したもの，C）先ず接点をポリ セットで被覆し，乾燥後充分な量のユニファス トで更に覆って継続菌を作成したもの，D）接 点に絶縁性の良いビニール樹脂㓌料（ビニロー ゼ，大日本塗料）を薄く叙って充分乾燥させた 後，充分な量のユニファストで被覆したもの， の 4 つの条件について更に検討した。この場合 にも継続歯は生理食塩液に漬け，30日間にわた り電気抵抗を測定した，その際の電気抵抗值の 変動を図1に示した．図1より明らかな如く， Dの条件が他の 3 者に比較して絶縁性にすぐれ ている事が明らかになったので，以後の in vivo 実験でもこの方法を採用した。

\section{2. 飼料硬度について}

現在入手可能なウサギ用飼料 8 種について硬 度を測定した結果が表 2 に示してある。備考欄 には，それぞれの飼料会社より提供された資料 を記載した。備考欄の測定值はいずれも 木屋式硬度計を使用して測定されたもの

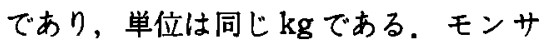
ント硬度計と木屋式硬度計での各測定值 は，1，2の例外を除きほぼ一致した成 績を示した.いずれの硬度計も錠郕の硬 度を測定する装置で，ネジの回転により バネが圧縮されるとその力がkgで表示さ れ，錠剤が破砕された時の圧を読取る様

て低く，且つ，硬化に長時間を要する事が判っ た。ポリセットは，硬化時間が短い利点はあっ たが，絶緑性がパイルBやユニファストに比較 すると幾分劣った，パイルBとユニファストと を比較した場合，後者は抗破砕力でやや劣った が絶縁性に勝り，しかも硬化時間が約 $1 / 4$ であ った.この実験結果より，以後の実験には専ら ユニファストを使用する事にした。

ユニファストは，継続雬においては最も高い 絶縁性を示したが，生体の場合には model 実 験よりも更に絶縁性の維持が困難である事が想 定されたので，更に高い絶縁性を維持させ得る 条件について検討した，即ち，風乾した歯根部 にネジ電極を植えこんでリード線をハンタ付け し，A）その後ユニファストのみで接点を被覆 し，継続歯を作成したもの，B）ユニファスト
になっている．表 2 の成績より明らかな如く， オリエンタル社 RC- 4 が最も硬度が低い事が判 明したので，以後の実験にはオリエンタル RC4 を使用した，また，新しく飼料を戝入した際 には必ず硬度試験を行い，飼料の硬度が当初の ものと一致する事を確認した。

3 、刺激電極を植えこんだウサギの飼料掑取量 及び体重の変動について

無処置のウサギ 5 匹について，1 日の飼料攝

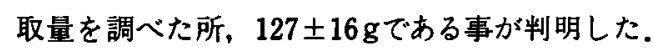
飼料箱の底部のものは当然掑取されにくいし, またあまりに大量の飼料を一時に投与しても 鸰料箱よりこぼれる量が多くなる事が判ったの で, 飼料は毎日午前 9 時に 1 日 1 回400g玍料箱 に入れ，その24時間後に残余量を科量してその 差より1 日の捸取量を求めた。また，1日1回 


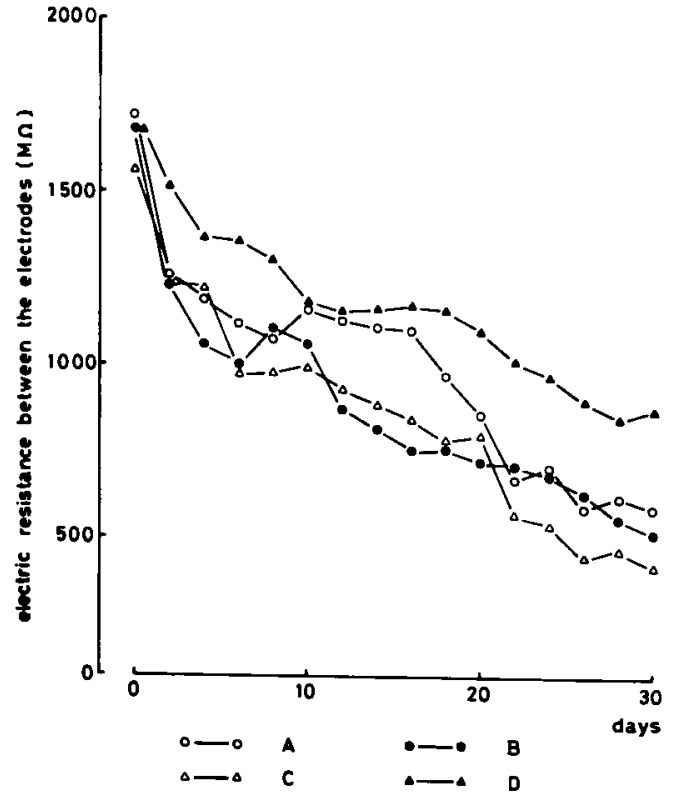

図1電極を被覆し，歯科用セメントで作成した経 続歯に植之込んだ電極間抵抗の変動.

表 2 ウサギ市眅固型咱料の硬度比較について

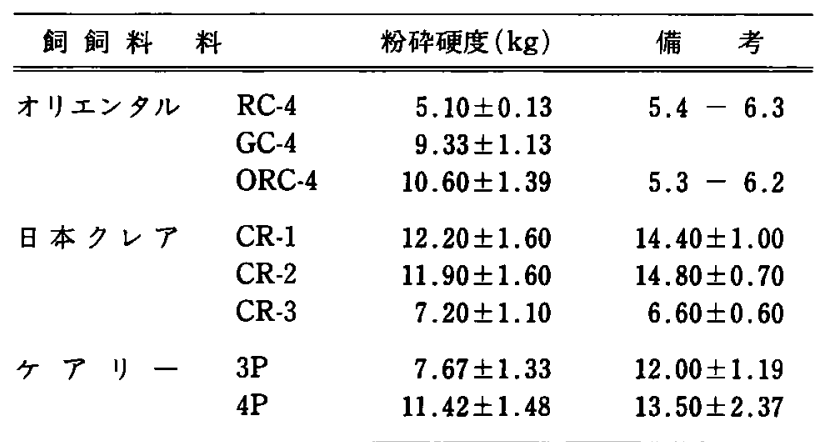

午前 9 時に体重測定した。

此等の結果をまとめたものが図 2 に示してあ る、歯髄刺激用電極を植之込まなかった対照群 のウサギにも pentobarbital $35 \mathrm{mg} / \mathrm{kg}$ の静注 は行なった。術後 $1-2$ 日間は, 手術群の飼料 摄取量は非常に低下したが，それ以後では对照 群との間に殆んど摄取量の差は見られない事が 判った．術後の食慨搨取量の低下にもかかわら ず，手術群の体重低下は観察されなかった。ま た，術後 7 日目に对照群と手術群を18時間絶食 させその後これらのウサギが飼料を捸取した $2.5,5,7.5,10,15$ 及び20秒後に開口马せ,
粉砕された飼料の大きさを調べたが，两群の間 で著しい差はなく，手術群も强い咀哷力をもっ ている事が判った。

4. 歯髄刺激後 VPM 及び RFで記録される 誘発電位について

パルス電流で歯髄を反復刺激した後, 刺激と 同側及U゙反对側の VPM 及U゙ RFで記録された 誘発電位の典型的な例を図 3 に示してある。刺 激と反对側の VPM 誘発電位は, $5.3 \mathrm{msec} の$ 潜 時の後, 波高 $29.7 \mu \mathrm{V}$ の陰性波が先ず記録され, ついで $10.2 \mathrm{msec}$ の潜時で $27.1 \mu \mathrm{V}$ の陽性波 が出現した，刺激歯䯣と同側の VPMでも類似 した波形をもつ二相性の電位が記録された。 RF の場合にも刺激と同側，反対側のいずれでも 類似した電位変動が記録された。これら誘発電 位の潜時及び最大電位は表 3 に一括して示した。 陰性波および陽性波のいずれも反対側で記録さ れた電位の方がより大きい值を示したが，潜時 は同側群の方が長かった。

10分以上の間隔をあけて反復して誘 発電位を記録した場合, 波形の潜時及 び最大振幅には殆んど変動せず，再現 性が非常に良い事が判った。また，一 定した波形をもつ誘発電位を反復記録 させる刺激条件として，刺激電圧 $6 \mathrm{~V}$ ， 刺激時間 $0.37 \mathrm{msec}$ が最も良い条件で ある事が判った。

刺激電極間の抵抗値は，実験期間中

1 日 1 回約 3 週間にわたり測定したが, いずれも $66-75 \mathrm{~K} \Omega$ の值を示した。一 方, 記録用電極間の抵抗値は 40-50 $\mathrm{K} \Omega$ の間に分布し，殆んど変動しなかった。 5. 歯䯣刺激後反対側の VPM 及び RFで記録 される誘発電位に及ばす morphine の影響 刺激と反対側の VPM 及び RFで記録される 誘発電位に对する morphine 投与後の影響を, 図 4-6に示した. morphine $2 \mathrm{mg} / \mathrm{kg}$ 静注後, VPM 誘発電位の陰性波は，投与 1 分後で既に 有意な減少を示し，10分後で効果は最大となり その後漸次回復した。また，陽性波も㓌性波電 位の変動と極めて類似した時間経過を示した(困 4, 図 5 ), RF 誘発電位の陰性波は, VPM 陰 性波の電位変動と類似した時間経過を示したが, 


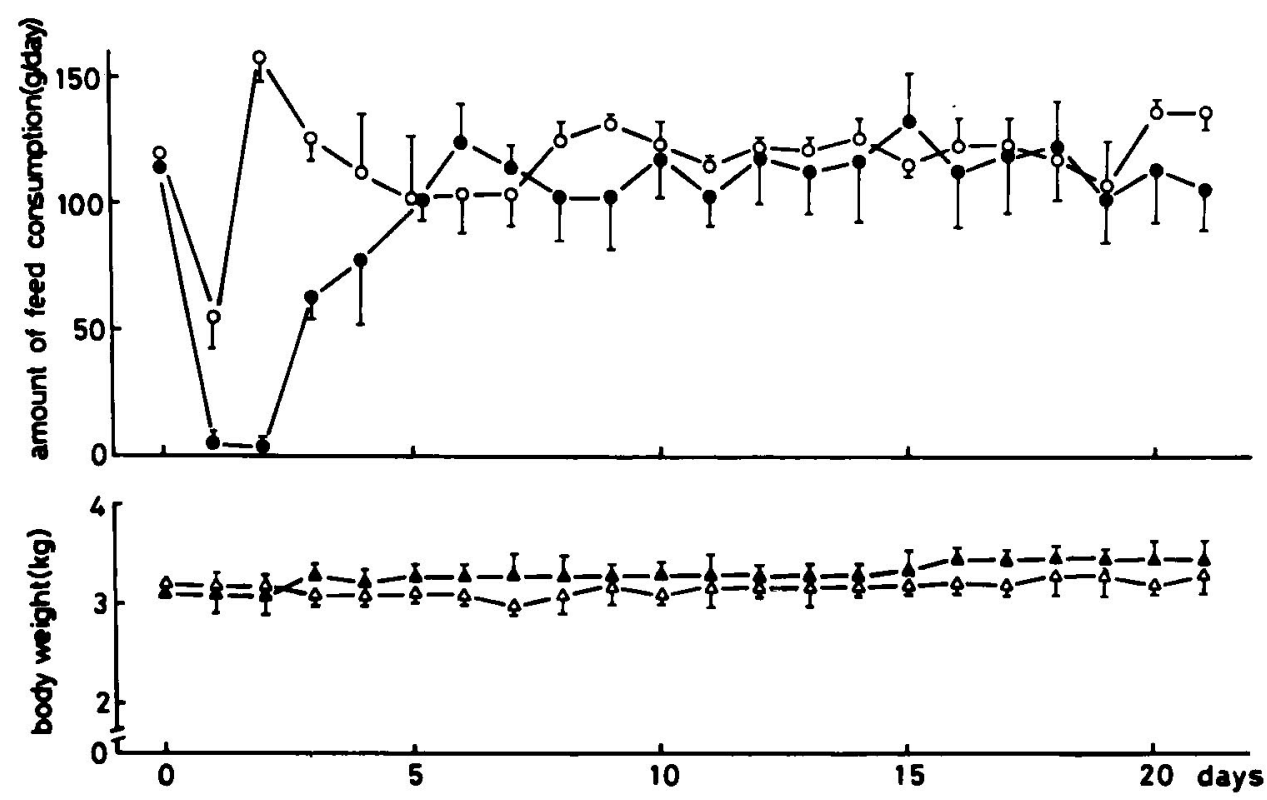

园 2 歯髄刺激用電極を植之込んだウサギの咱料掑取量及U゙体重の変動

○一一 对照ウサギの飼料攝取量

-——電極植込みウサギの飼料捸取量

$\triangle \longrightarrow \triangle$ 对照ウサギの体重

$\Delta$ - $\Delta$ 電極值込みウサギの体重

ipsilateral
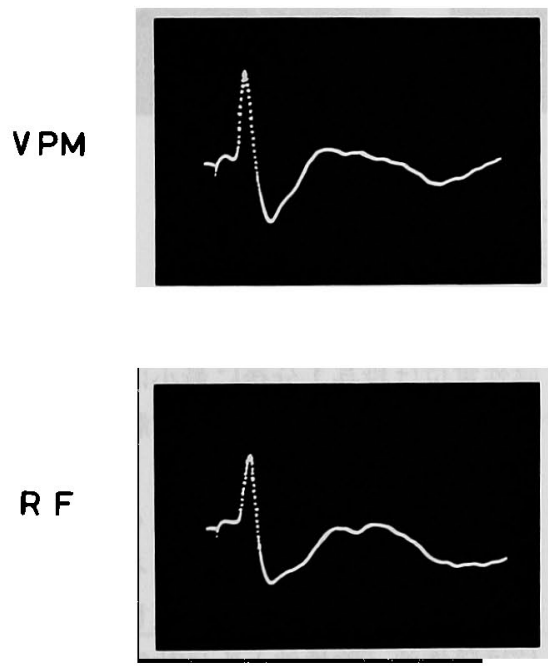

contralateral
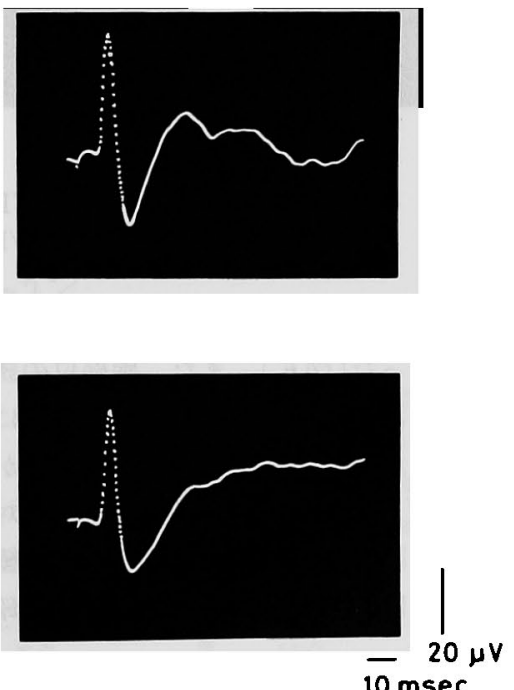

図 3 歯髄刺激により VPM 及びRFで記録される誘発電位の典型的な 1 例. 右下隅の bar は，それぞれ $10 \mathrm{msec}$, 及び $20 \mu \mathrm{V} の$ calibrationを示している。 
表 3 畨骵刺激によりVPM 及びRFで記録される誘発電位

\begin{tabular}{|c|c|c|c|c|}
\hline \multirow[b]{2}{*}{ 誘 発 電 位 } & 反 & 対 & 同 & 側 \\
\hline & VPM & $\mathrm{RF}$ & VPM & RF \\
\hline 陰性波の潜時（msec） & $5.3 \pm 0.3$ & $4.7 \pm 0.3$ & $6.3 \pm 0.2$ & $6.4 \pm 0.3$ \\
\hline 陰性波の電位 $(\mu \mathrm{V})$ & $29.7 \pm 6.9$ & $31.2 \pm 7.1$ & $24.3 \pm 3.3$ & $21.2 \pm 2.4$ \\
\hline 陽性波の潜時（msec） & $10.2 \pm 0.8$ & $11.2 \pm 0.8$ & $12.9 \pm 0.5$ & $12.8 \pm 0.4$ \\
\hline 陽性波の電位 $(\mu \mathrm{V})$ & $27.1 \pm 5.7$ & $20.2 \pm 4.7$ & $20.0 \pm 3.0$ & $17.7 \pm 1.7$ \\
\hline 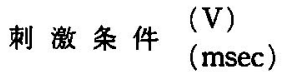 & $\begin{array}{c}6.0 \pm 0.9 \\
0.37 \pm 0.07\end{array}$ & $\begin{array}{c}6.0 \pm 0.9 \\
0.37 \pm 0.07\end{array}$ & $\begin{array}{c}6.0 \pm 0.9 \\
0.37 \pm 0.07\end{array}$ & $\begin{array}{c}6.2 \pm 0.8 \\
0.37 \pm 0.04\end{array}$ \\
\hline
\end{tabular}

Before

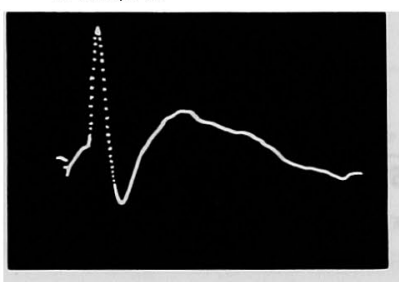

$30 \mathrm{~min}$

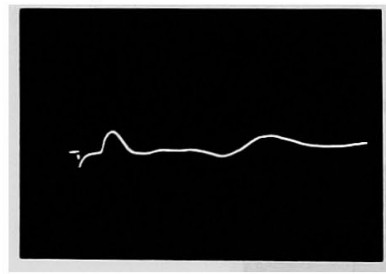

$1 \mathrm{~min}$

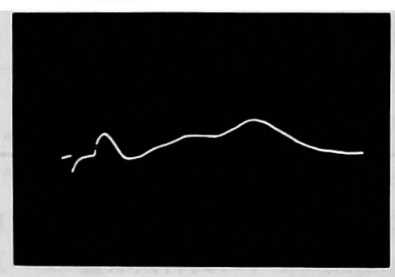

$60 \mathrm{~min}$

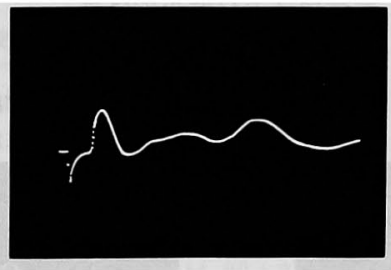

$10 \mathrm{~min}$

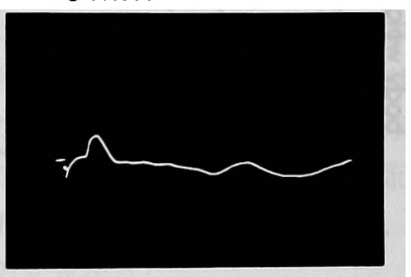

$180 \mathrm{~min}$

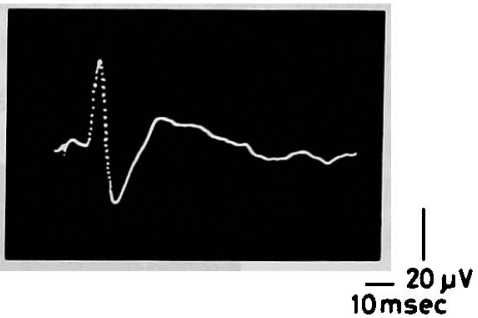

図 4 刺激と反对側の VPM で記録される誘発電位に对する morphine $(2 \mathrm{mg} / \mathrm{kg})$ 静注の影響.

陽性波に対する morphine の抑制効果は弱く50 \%以下にとどまった(図 6 ). また，両部位の誘 発電位とも陰性波潜時が，10，30及び60分後に 僅かに延長したが，対照群との差は有意でなか った。同側の VPM 及び RF 誘発電位も，反对 側で記録された陰性波および陽性波の減衰と極 めて類似した時間的経過を示すのを少数例で確 認した $(n=3)$.

6. 歯䯣刺激後反対側の VPM 及び RFで記録 される誘発電位に対する pentazocineの影 響

反对側の VPM 及び RF で記録される誘発電 位に对する pentazocine 投与の影響を図 7,8
に示した. pentazocine $5 \mathrm{mg} / \mathrm{kg}$ 静注後, VPM 陰性電位は投与 1 分後に最小になり，その後 30 分間にわたりほほ同程度の抑制効果が持続した が，その後急速に回復した．陽性波に对する pentazocine の抑制効果は弱く，1 分後の波高 が有意に抑制されただけで，その後は陰性波と ほほ平行した時間経過で回復した，RF 誘発電 位は陽性波，除性波ともに約 $50 \%$ 程度の抑制を

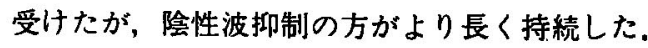
なお, pentazocine 投与後いずれの誘発電位に おいても, 潜時は殆んど変動しなかった。非常 に類似した抑制効果は，同側で記録された誘発 電位でもやはり認められた $(n=3)$. 


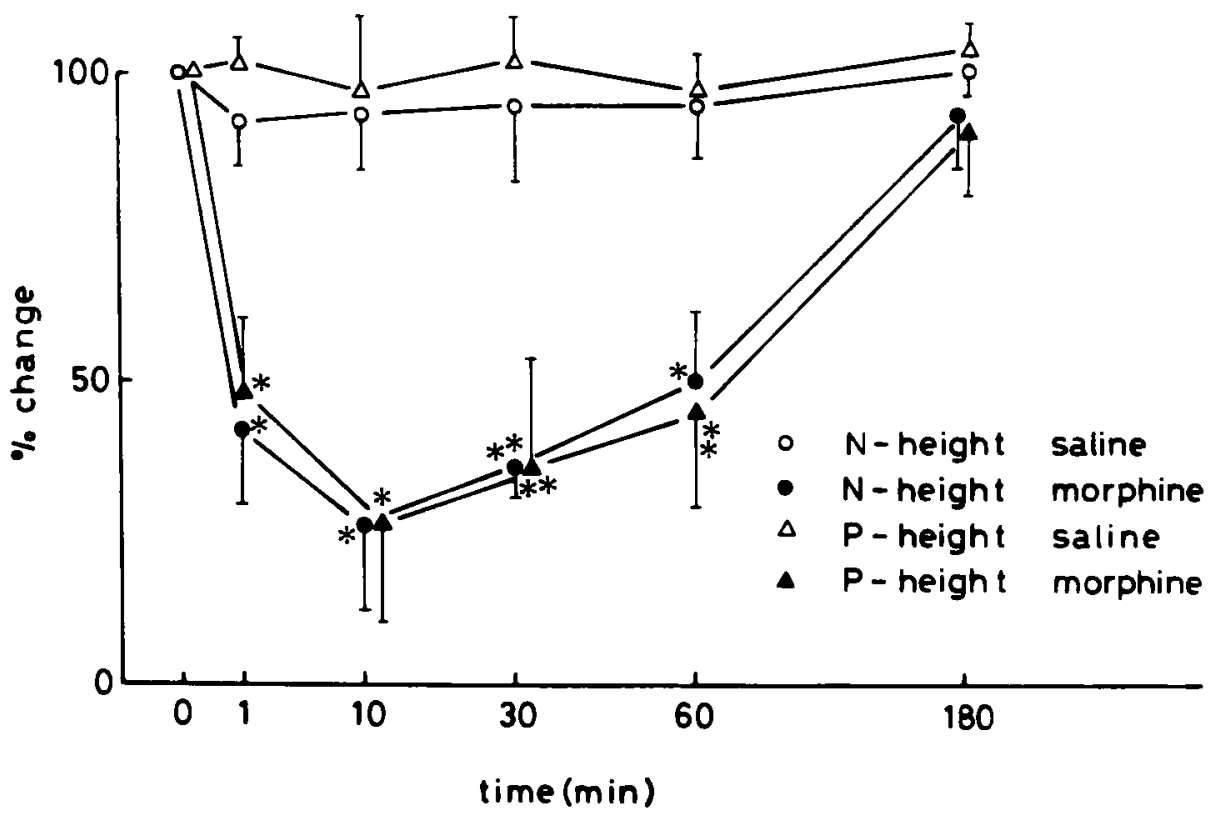

因 5 刺激と反对側の VPM で記録される誘発電位に対する morphine ( $2 \mathrm{mg} /$ $\mathrm{kg}$ ) 静注の影響。誘発電位の陰性波電位 (N-height) と陽性波電位 (Pheight）の平均值と標染誤差の時間的変動を示している，对照時の電位を $100 \%$ してその後の電位変動を百分率で示した。 ${ }^{*} \mathrm{P}<0.05,{ }^{*} \mathrm{P}<0.01$ $(n=5)$.

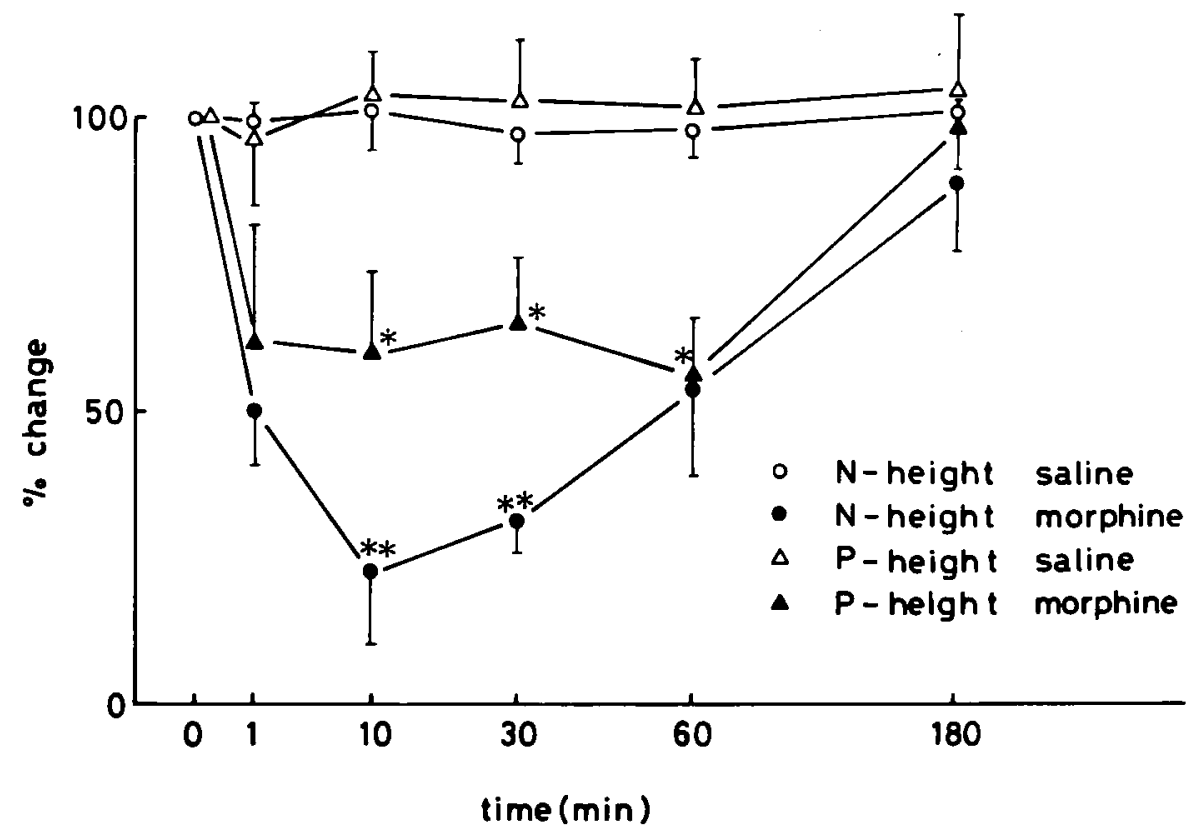

図6 刺激と反対側の RF で記録される誘発電位に对する morphine ( $2 \mathrm{mg}$ / $\mathrm{kg}$ ）静注の影響.

*P $\mathrm{P}<0.05,{ }^{* *} \mathrm{P}<0.01(\mathrm{n}=5)$. 


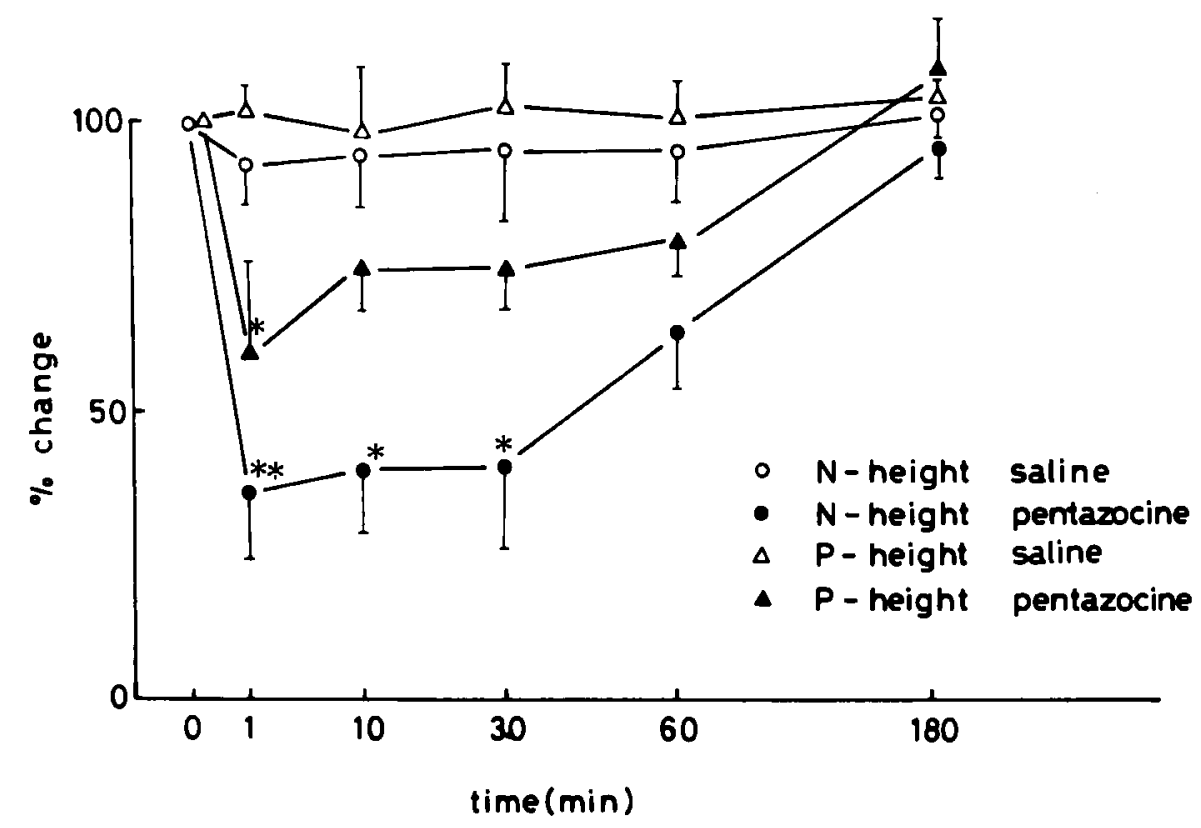

图 7 刺激と反对側の VPM で記録される誘発電位に対する pentazocine $\left(5 \mathrm{mg} / \mathrm{kg}\right.$ ) 静注の影響。 ${ }^{*} \mathrm{P}<0.05,{ }^{*} \mathrm{P}<0.01 \quad(\mathrm{n}=5)$.

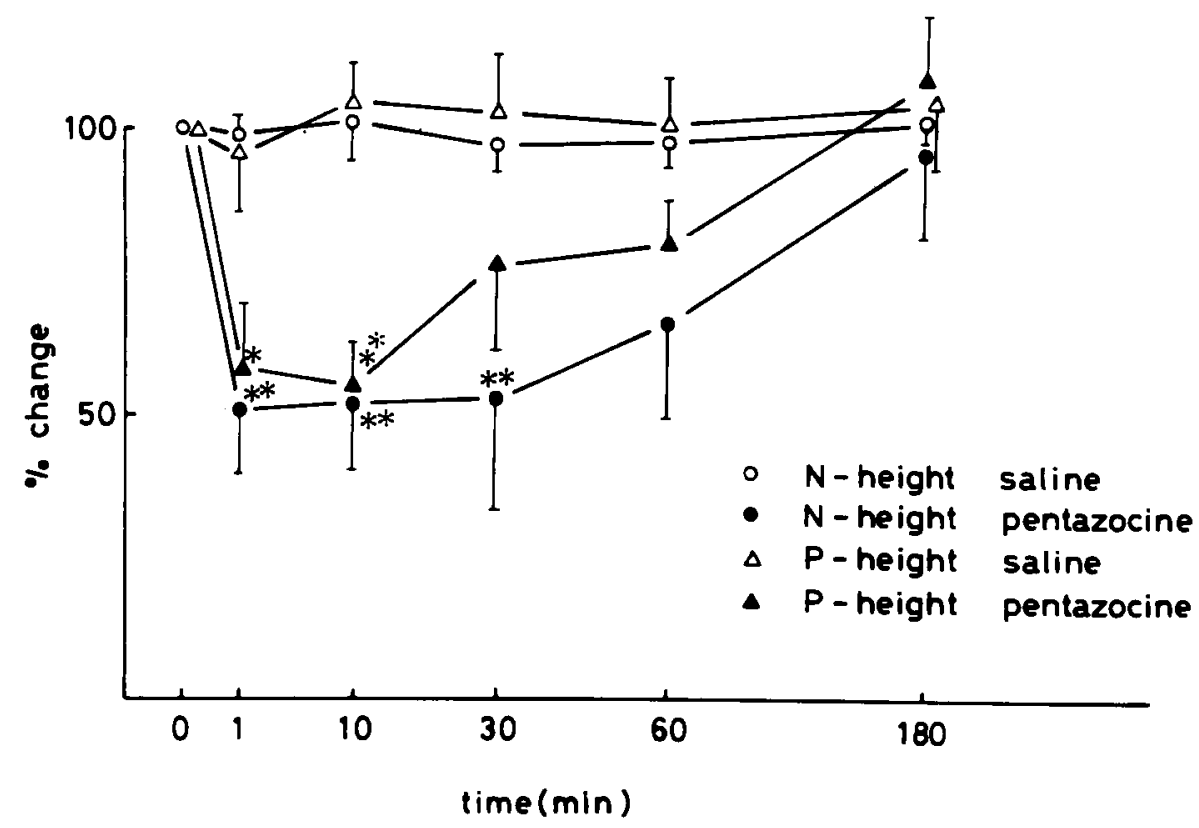

図8 刺激と反対側の RF で記録される誘発電位に对する pentazocine $(5 \mathrm{mg} / \mathrm{kg})$ 静注の影響. $\quad$ " $\mathrm{P}<0.05,{ }^{*} \mathrm{P}<0.01(\mathrm{n}=5)$.

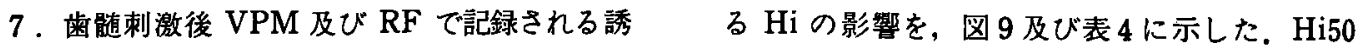
発電位に対する $\mathrm{Hi}$ 側脳室内投与の影響. 反対側のVPMで記録された誘発電位に対す $\mu \mathrm{g} /$ head の脳室内投与の際には，30分後の陰性 波及び陽性波の最大電位がやや減少したが，差 


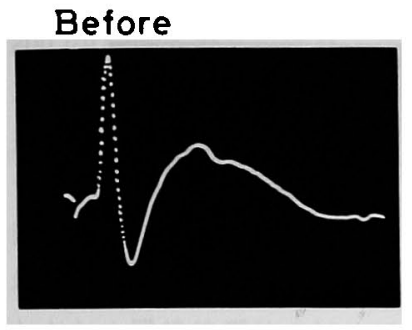

$30 \mathrm{~min}$
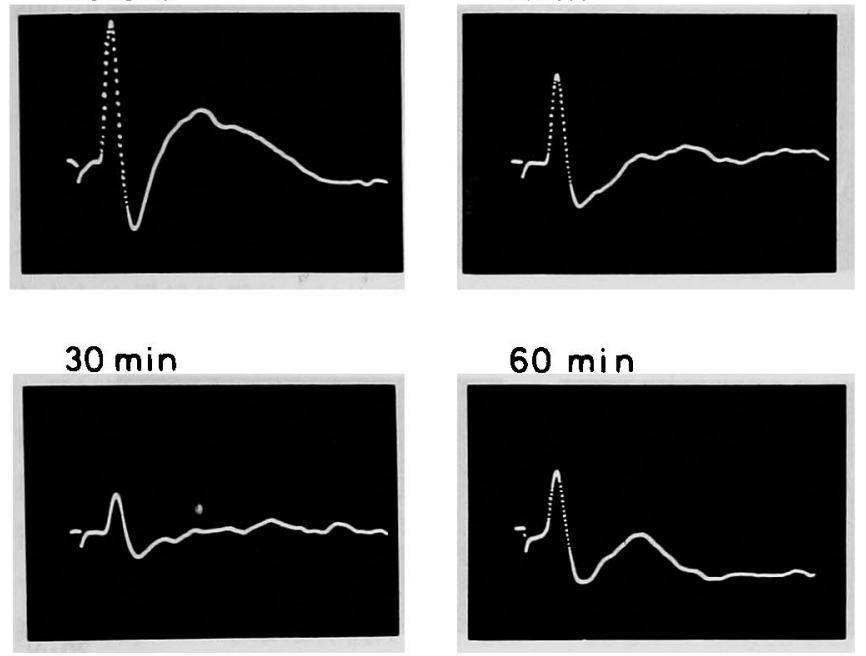

$10 \mathrm{~min}$

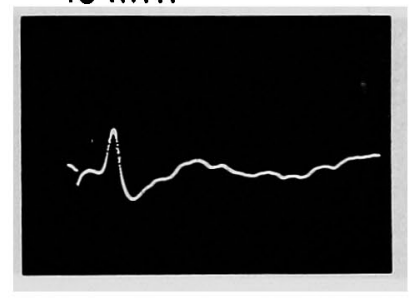

$180 \mathrm{~min}$

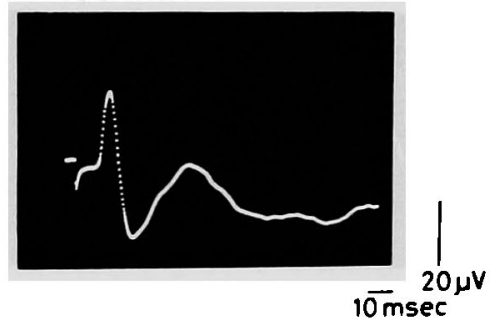

図 9 刺激と反对側の VPM で記録される誘発電位に对するヒスタミン $200 \mu \mathrm{g}$ 脳室内投与の影響.

表 4 刺激と反对側の VPM で記録される誘発電位に対するヒスタミン脳室内投与の影響

\begin{tabular}{|c|c|c|c|c|c|c|c|}
\hline 誘発電位 & $\mathrm{Hi}$ 投与量 $(\mu \mathrm{g})$ & before & 1 & 10 & 30 & 60 & $180 \mathrm{~min}$. \\
\hline \multirow[t]{4}{*}{ 陰性波の潜時 } & 0 & $100 \pm 0$ & $100 \pm 6$ & $100 \pm 6$ & $100 \pm 6$ & $100 \pm 6$ & $100 \pm 6$ \\
\hline & 50 & $100 \pm 0$ & $100 \pm 6$ & $100 \pm 6$ & $100 \pm 6$ & $100 \pm 6$ & $100 \pm 6$ \\
\hline & 100 & $100 \pm 0$ & $87 \pm 7$ & $98 \pm 6$ & $98 \pm 6$ & $98 \pm 6$ & $98 \pm 6$ \\
\hline & 200 & $100 \pm 0$ & $102 \pm 10$ & $108 \pm 9$ & $92 \pm 11$ & $98 \pm 12$ & $98 \pm 8$ \\
\hline \multirow[t]{4}{*}{ 陰性波の電位 } & 0 & $100 \pm 0$ & $100 \pm 17$ & $104 \pm 16$ & $99 \pm 10$ & $101 \pm 15$ & $102 \pm 12$ \\
\hline & 50 & $100 \pm 0$ & $84 \pm 18$ & $94 \pm 8$ & $85 \pm 11$ & $88 \pm 12$ & $100 \pm 13$ \\
\hline & 100 & $100 \pm 0$ & $77 \pm 24$ & $54 \pm 15^{*}$ & $49 \pm 30$ & $60 \pm 17$ & $93 \pm 11$ \\
\hline & 200 & $100 \pm 0$ & $76 \pm 25$ & $29 \pm 23^{*}$ & $38 \pm 16^{* *}$ & $42 \pm 8^{* *}$ & $73 \pm 13$ \\
\hline \multirow[t]{4}{*}{ 陽性波の潜時 } & 0 & $100 \pm 0$ & $100 \pm 4$ & $100 \pm 4$ & $100 \pm 4$ & $100 \pm 4$ & $100 \pm 4$ \\
\hline & 50 & $100 \pm 0$ & $98 \pm 9$ & $98 \pm 9$ & $108 \pm 7$ & $98 \pm 3$ & $98 \pm 9$ \\
\hline & 100 & $100 \pm 0$ & $99 \pm 9$ & $96 \pm 7$ & $99 \pm 6$ & $102 \pm 11$ & $90 \pm 6$ \\
\hline & 200 & $100 \pm 0$ & $94 \pm 4$ & $103 \pm 9$ & $104 \pm 12$ & $101 \pm 8$ & $101 \pm 7$ \\
\hline \multirow[t]{4}{*}{ 陽性波の電位 } & 0 & $100 \pm 0$ & $104 \pm 11$ & $106 \pm 8$ & $106 \pm 9$ & $104 \pm 4$ & $105 \pm 8$ \\
\hline & 50 & $100 \pm 0$ & $89 \pm 16$ & $88 \pm 9$ & $71 \pm 20$ & $91 \pm 10$ & $118 \pm 11$ \\
\hline & 100 & $100 \pm 0$ & $76 \pm 19$ & $64 \pm 17^{*}$ & $58 \pm 7^{* *}$ & $85 \pm 8$ & $100 \pm 14$ \\
\hline & 200 & $100 \pm 0$ & $70 \pm 12$ & $36 \pm 21^{*}$ & $40 \pm 7^{* *}$ & $52 \pm 31$ & $89 \pm 14$ \\
\hline
\end{tabular}

陰性波潜時： $5.2 \pm 0.2 \mathrm{msec}$, 陰性波電位： $30.1 \pm 1.7 \mu \mathrm{V}$

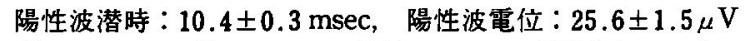
${ }^{*} \mathrm{P}<0.05,{ }^{*} \mathrm{P}<0.01$ 数值は mean \pm SEM $(\mathrm{n}=5)$

は有意ではなかった．Hi $100 \mu \mathrm{g} / \mathrm{head}$ 投与で は, 陰䢀波電位が10分後に, 陽性波電位は10 30分後に，それぞれ有意な減少を示した，200 $\mu \mathrm{g} /$ head 投与の際には，㓌性波は10～60分間に
わたり減少し，陽性波は10３0分後にそれぞれ 減少し，いずれも对照群との差は有意であった。 潜時は，いずれの場合でもほとんど変化しなか った. 

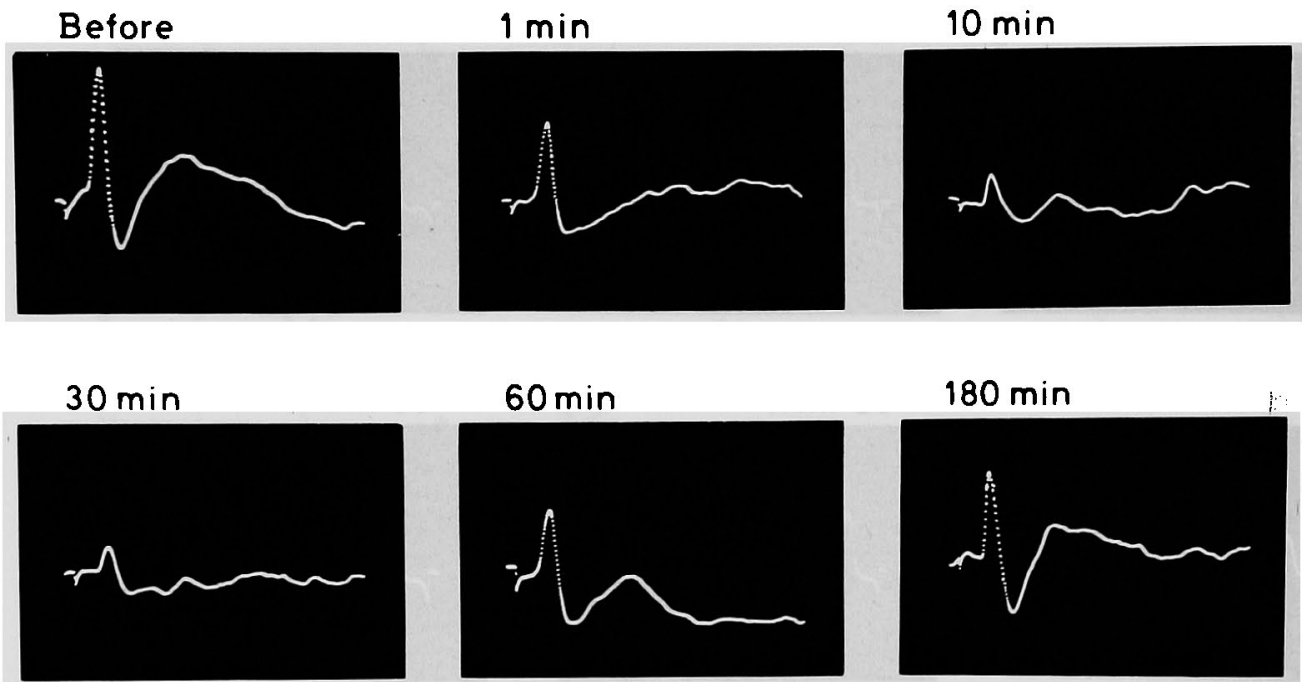

$60 \min$

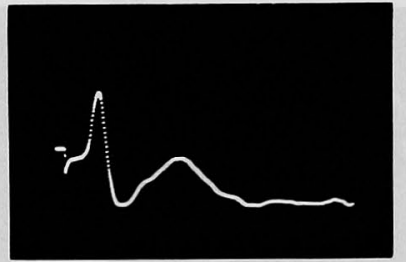

$180 \mathrm{~min}$

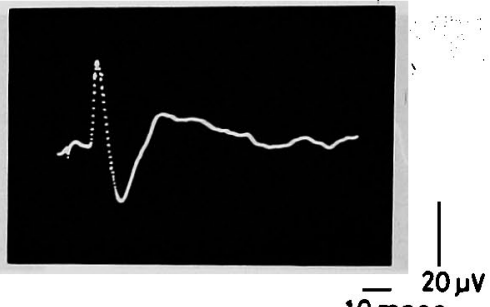

$10 \mathrm{msec}$

図10 刺激と同㑡の VPM で記録されれる誘発電位に対するヒスタミン $200 \mu \mathrm{g} の$ 影響.

表 5 刺激と同側の VPM で記録される誘発電位に对するヒスタミン脳室内投与の影暗

\begin{tabular}{lrrrrrrr}
\hline 誘発電位 & Hi 投与量 $(\mu \mathrm{g})$ & before & 1 & 10 & 30 & 60 & $180 \mathrm{~min}$ \\
\hline 陰性波の潜時 & 0 & $100 \pm 0$ & $97 \pm 10$ & $106 \pm 16$ & $100 \pm 6$ & $97 \pm 8$ & $100 \pm 6$ \\
& 50 & $100 \pm 0$ & $100 \pm 8$ & $97 \pm 5$ & $107 \pm 9$ & $97 \pm 0$ & $93 \pm 7$ \\
& 100 & $100 \pm 0$ & $95 \pm 10$ & $103 \pm 9$ & $100 \pm 13$ & $95 \pm 7$ & $100 \pm 16$ \\
& 200 & $100 \pm 0$ & $92 \pm 10$ & $106 \pm 4$ & $97 \pm 5$ & $98 \pm 3$ & $103 \pm 6$ \\
陰性波の電位 & 0 & $100 \pm 0$ & $92 \pm 11$ & $95 \pm 13$ & $95 \pm 15$ & $94 \pm 11$ & $102 \pm 13$ \\
& 50 & $100 \pm 0$ & $97 \pm 12$ & $89 \pm 20$ & $80 \pm 14$ & $85 \pm 17$ & $96 \pm 11$ \\
& 100 & $100 \pm 0$ & $88 \pm 10$ & $86 \pm 8$ & $55 \pm 24$ & $79 \pm 12$ & $104 \pm 20$ \\
& 200 & $100 \pm 0$ & $64 \pm 17$ & $29 \pm 19^{*}$ & $35 \pm 13^{*}$ & $45 \pm 14^{*}$ & $84 \pm 13$ \\
陽性波の潜時 & 0 & $100 \pm 0$ & $100 \pm 3$ & $97 \pm 6$ & $105 \pm 5$ & $100 \pm 6$ & $102 \pm 6$ \\
& 50 & $100 \pm 0$ & $93 \pm 11$ & $96 \pm 12$ & $98 \pm 8$ & $94 \pm 11$ & $96 \pm 12$ \\
& 100 & $100 \pm 0$ & $95 \pm 10$ & $96 \pm 10$ & $99 \pm 9$ & $99 \pm 13$ & $94 \pm 11$ \\
& 200 & $100 \pm 0$ & $97 \pm 12$ & $98 \pm 12$ & $105 \pm 7$ & $94 \pm 8$ & $95 \pm 6$ \\
& 0 & $100 \pm 0$ & $107 \pm 13$ & $97 \pm 10$ & $102 \pm 10$ & $96 \pm 8$ & $108 \pm 21$ \\
& 50 & $100 \pm 0$ & $96 \pm 20$ & $73 \pm 18$ & $79 \pm 17$ & $95 \pm 18$ & $96 \pm 19$ \\
& 100 & $100 \pm 0$ & $85 \pm 13$ & $95 \pm 14$ & $60 \pm 17^{*}$ & $73 \pm 18$ & $105 \pm 12$ \\
& 200 & $100 \pm 0$ & $77 \pm 13$ & $57 \pm 14^{*}$ & $56 \pm 12^{*}$ & $84 \pm 12$ & $101 \pm 8$ \\
\hline
\end{tabular}

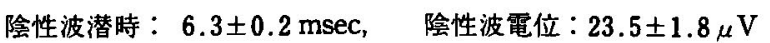

陽性波潜時：12.5 $\pm 0.6 \mathrm{msec}$, 陽性波電位: $19.8 \pm 1.9 \mu \mathrm{V}$

$\cdot \mathrm{P}<0.05$ 数值は mean \pm SEM $(n=5)$

同側の VPM で記録される誘発電位に対する Hi 投与の影響を図10及び表 5に示した.Hi 50 $\mu \mathrm{g} /$ head 投与の場合には, 10 - 30分後に記録さ
れる陰性波及び陽性波の電位の大きさは軽度に 減少したが，対照群との差は有意でなかった。 $100 \mu \mathrm{g} / \mathrm{head}$ 投与群では，30分後の陽性波は有 
意に減少したが陰性波の減衰は有意でなかった。 $200 \mu \mathrm{g} / \mathrm{head}$ 投与の場合, 陰性波の電位は投与 10６0分間，陽性波の電位は投与後10３0分間 抑制された，潜時は，陰性波，陽性波のいずれ でもほとんど変化しなかった.VPMにおける 陰性電位は，反对側および同側刺激のいずれの 場合でも類似した減少の時間的経過を示した。 しかし, 陽性波電位の減少は反对側誘発電位の 方がより顕著で且つ長く持続した。

反対側ならびに同側の RFで記録される誘発 電位に対する $\mathrm{Hi} の$ 影響を, 表 6 及び表 7 に一 括して示した，反対側の RFで記録された電位 変動では, $200 \mu \mathrm{g} / \mathrm{head}$ 投与後陰性波電位が30 ～60分後に，陽性波電位が10～60分後で有意に 減少した，RFでは陰性波及び陽性波いずれも 反对側電位の減少がより顕著であったが, VPM 同様その抑制効果は陽性波に著明に出現した。

$\mathrm{Hi}$ 投与後, 反対側及び同側 VPM 及び RFで 記録される誘発電位の陽性波および院性波の電 位堿少には，いすれれも用量依存性が観察され， 作用の持続時間も用量の增大に比例して延長し た.
8. Hi $200 \mu \mathrm{g} / \mathrm{head}$ 投与によるVPM及びRF 誘発電位抑制作用に及ほす pyrilamine 同 時投与の影響

反対側刺激後の VPM 及び RF 誘発電位に対 する Hi の抑制効果が, H1 blocker である pyrilamine の同時投与により如何なる影響を受け るのかについて検討した. pyrilamine $20 \mu \mathrm{g} /$ headの脳室内投与は，これら两部位で記録さ れる誘発電位のいずれの成分に对しても全く抑 制効果を示さない事が判った（図11，12）.本実 験で観察記録されているすへての誘発電位成分 に対して顕著な抑制効果を示す $\mathrm{Hi} 200 \mu \mathrm{g} / \mathrm{head}$ と pyrilamine $20 \mu \mathrm{g} / \mathrm{head}$ を併用した場合, VPM 及び RF の陰性波及び陽性波の波高はいずれ も10\%前後の減少にとどまり，いずれの測定時 間においても对照群との間で有意差はなかった (図11，12）。しかし，同時に行った $\mathrm{Hi}$ 単独投 与群の誘発電位は, 陰性波及U゙陽性波とも著明 に抑制されている. Hi 単独投与群と $\mathrm{Hi}+$ pyrilamine 投与群との間で誘発電位の両成分につ いて各測定時間毎に差の有意性を検討した所， 投与後10 30分の間で両群の波高の差は有意で

表 6 刺激と反対側の RF で記録される誘発電位に对するヒスタミン脳室内投与の影響

\begin{tabular}{|c|c|c|c|c|c|c|c|}
\hline 誘発電位 I & $\mathrm{Hi}$ 投与量 $(\mu \mathrm{g})$ & before & $\mathbf{1}$ & 10 & 30 & 60 & $180 \mathrm{~min}$ \\
\hline \multirow[t]{4}{*}{ 陰性波の潜時 } & 0 & $100 \pm 0$ & $100 \pm 10$ & $100 \pm 12$ & $100 \pm 10$ & $100 \pm 10$ & $100 \pm 10$ \\
\hline & 50 & $100 \pm 0$ & $108 \pm 6$ & $100 \pm 2$ & $100 \pm 4$ & $100 \pm 4$ & $98 \pm 2$ \\
\hline & 100 & $100 \pm 0$ & $96 \pm 7$ & $96 \pm 7$ & $98 \pm 9$ & $104 \pm 12$ & $98 \pm 6$ \\
\hline & 200 & $100 \pm 0$ & $109 \pm 15$ & $105 \pm 7$ & $100 \pm 7$ & $93 \pm 15$ & $100 \pm 7$ \\
\hline \multirow[t]{4}{*}{ 陰性波の電位 } & 0 & $100 \pm 0$ & $103 \pm 14$ & $96 \pm 12$ & $101 \pm 13$ & $101 \pm 13$ & $111 \pm 12$ \\
\hline & 50 & $100 \pm 0$ & $96 \pm 6$ & $82 \pm 16$ & $88 \pm 12$ & $91 \pm 12$ & $102 \pm 12$ \\
\hline & 100 & $100 \pm 0$ & $74 \pm 13$ & $65 \pm 19$ & $61 \pm 14$ & $71 \pm 16$ & $84 \pm 8$ \\
\hline & 200 & $100 \pm 0$ & $66 \pm 18$ & $40 \pm 28$ & $28 \pm 17^{* *}$ & $43 \pm 14^{*}$ & $78 \pm 11$ \\
\hline \multirow[t]{4}{*}{ 陽性波の潜時 } & 0 & $100 \pm 0$ & $91 \pm 13$ & $94 \pm 14$ & $94 \pm 9$ & $97 \pm 16$ & $97 \pm 16$ \\
\hline & 50 & $100 \pm 0$ & $95 \pm 19$ & $92 \pm 17$ & $95 \pm 14$ & $95 \pm 19$ & $95 \pm 18$ \\
\hline & 100 & $100 \pm 0$ & $100 \pm 1$ & $89 \pm 7$ & $98 \pm 11$ & $108 \pm 1$ & $93 \pm 6$ \\
\hline & 200 & $100 \pm 0$ & $107 \pm 14$ & $100 \pm 12$ & $100 \pm 12$ & $104 \pm 12$ & $104 \pm 12$ \\
\hline \multirow[t]{4}{*}{ 陽性波の電位 } & 0 & $100 \pm 0$ & $106 \pm 9$ & $113 \pm 16$ & $102 \pm 11$ & $115 \pm 15$ & $116 \pm 15$ \\
\hline & 50 & $100 \pm 0$ & $87 \pm 15$ & $88 \pm 13$ & $99 \pm 16$ & $103 \pm 16$ & $104 \pm 17$ \\
\hline & 100 & $100 \pm 0$ & $71 \pm 18$ & $64 \pm 25$ & $80 \pm 14$ & $105 \pm 8$ & $120 \pm 11$ \\
\hline & 200 & $100 \pm 0$ & $58 \pm 33$ & $28 \pm 18^{* *}$ & $38 \pm 15^{* *}$ & $55 \pm 15^{*}$ & $105 \pm 13$ \\
\hline
\end{tabular}

陰性波潜時： $4.8 \pm 0.2 \mathrm{msec}$,

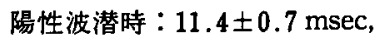
$* \mathrm{P}<0.05, \quad * \mathrm{P}<0.01$
陰性波電位: $30.2 \pm 1.4 \mu \mathrm{V}$

陽性波電位: $21.4 \pm 2.0 \mu \mathrm{V}$

数值は mean \pm SEM $(n=5)$ 
表 7 刺激と同側の RF で記録される誘発電位に対するヒスタミン脳室内投与の影䭚

\begin{tabular}{cccccccc}
\hline 誘発電位 & Hi投与量 $(\mu \mathrm{g})$ & before & 1 & 10 & 30 & 60 & $180 \mathrm{~min}$ \\
\hline 陰性波の潜時 & 0 & $100 \pm 0$ & $107 \pm 8$ & $107 \pm 9$ & $107 \pm 9$ & $103 \pm 8$ & $103 \pm 8$ \\
& 50 & $100 \pm 0$ & $102 \pm 0$ & $102 \pm 0$ & $110 \pm 5$ & $110 \pm 5$ & $110 \pm 5$ \\
& 100 & $100 \pm 0$ & $102 \pm 9$ & $98 \pm 6$ & $90 \pm 14$ & $98 \pm 3$ & $102 \pm 14$ \\
& 200 & $100 \pm 0$ & $100 \pm 14$ & $100 \pm 10$ & $108 \pm 11$ & $114 \pm 10$ & $108 \pm 9$ \\
陰性波の電位 & 0 & $100 \pm 0$ & $99 \pm 4$ & $101 \pm 9$ & $97 \pm 6$ & $96 \pm 6$ & $101 \pm 8$ \\
& 50 & $100 \pm 0$ & $86 \pm 14$ & $90 \pm 20$ & $76 \pm 15$ & $92 \pm 15$ & $102 \pm 10$ \\
& 100 & $100 \pm 0$ & $82 \pm 17$ & $79 \pm 8$ & $70 \pm 16$ & $72 \pm 16$ & $105 \pm 13$ \\
& 200 & $100 \pm 0$ & $93 \pm 12$ & $50 \pm 16^{*}$ & $45 \pm 14^{*}$ & $48 \pm 12^{*}$ & $97 \pm 13$ \\
陽性波の潜時 & 0 & $100 \pm 0$ & $98 \pm 11$ & $95 \pm 11$ & $98 \pm 12$ & $101 \pm 12$ & $98 \pm 11$ \\
& 50 & $100 \pm 0$ & $98 \pm 15$ & $100 \pm 14$ & $92 \pm 13$ & $100 \pm 13$ & $102 \pm 15$ \\
& 100 & $100 \pm 0$ & $98 \pm 10$ & $95 \pm 13$ & $103 \pm 10$ & $99 \pm 10$ & $102 \pm 9$ \\
& 200 & $100 \pm 0$ & $95 \pm 14$ & $92 \pm 13$ & $99 \pm 9$ & $95 \pm 10$ & $95 \pm 10$ \\
陽性波の電位 & 0 & $100 \pm 0$ & $98 \pm 15$ & $97 \pm 10$ & $103 \pm 14$ & $102 \pm 11$ & $105 \pm 18$ \\
& 50 & $100 \pm 0$ & $114 \pm 17$ & $79 \pm 13$ & $73 \pm 14$ & $86 \pm 17$ & $103 \pm 17$ \\
& 100 & $100 \pm 0$ & $86 \pm 13$ & $83 \pm 25$ & $58 \pm 20$ & $74 \pm 17$ & $105 \pm 18$ \\
& 200 & $100 \pm 0$ & $48 \pm 14^{*}$ & $57 \pm 12^{*}$ & $60 \pm 8^{*}$ & $85 \pm 14$ & $87 \pm 13$ \\
\hline
\end{tabular}

陰性波潜時： $6.2 \pm 0.2 \mathrm{msec}$, 陰性波電位 : $22.7 \pm 1.4 \mu \mathrm{V}$

陽性波潜時：12.5 $\pm 0.6 \mathrm{msec}$, 陽性波電位： $19.4 \pm 1.5 \mu \mathrm{V}$

$\mathrm{P}<0.05$ 数值は mean $\pm \mathrm{SEM}(\mathrm{n}=5)$

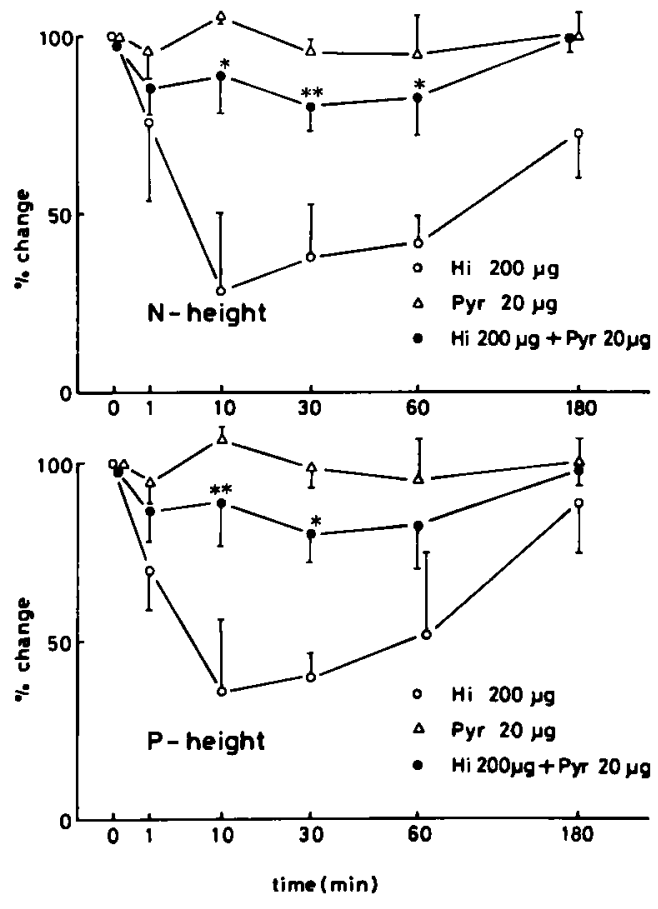

図11ヒス夕ミンの VPM 誘発電位抑制作用に及ほ 于 pyrilamine (Pyr) の影留.上段は院性波、 下段は陽性波電位変動の時間的経過。 ${ }^{*} \mathrm{P}<0.05,{ }^{* *} \mathrm{P}<0.01(\mathrm{n}=5)$

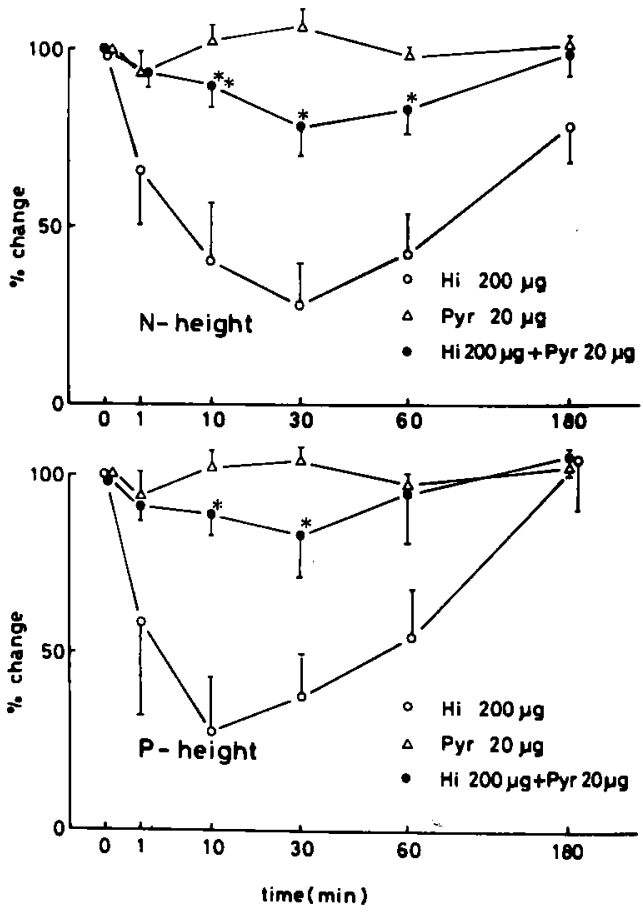

図12ヒスタミンのRF 誘発電位抑制作用に及洔す

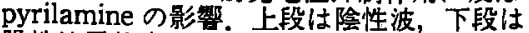
陽性波電位変動の時間的経過。 ${ }^{*} \mathrm{P}<0.05,{ }^{*} \mathrm{P}<0.01(\mathrm{n}=5)$ 
あった。

9. Hi $200 \mu \mathrm{g} / \mathrm{head}$ 投与によるVPM 及び RF 誘発電位抑制作用に及ばす cimetidineの影 響

$\mathrm{Hi}$ の中枢作用には， $\mathrm{H}_{1}$ receptor のみならず $\mathrm{H}_{2}$ receptor も関与している知見が報告されて いるので10), 反对側歯髄刺激によるVPM 及び $\mathrm{RF}$ 誘発電位に对する $\mathrm{Hi}$ の抑制効果を $\mathrm{H}_{2}$ block. er である cimetidine の同時投与がどの様に修 飾し得るのかについて検討した。

cimetidine $20 \mu \mathrm{g}$ は, 刺激と反对側で記録さ れた VPM 及び RF の誘発電位の波形のみなら ず，潜時にも全く影響しなかった（図13，14）。
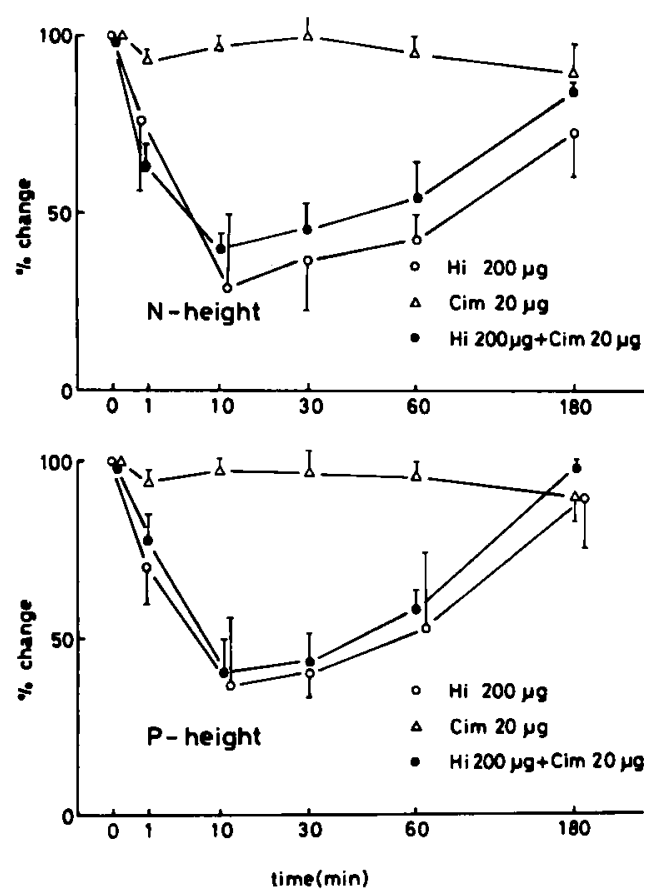

図13 ヒスタミンの VPM 誘発電位抑制作用に及ほ す cimetidine (Cim) の影笠. 上段は除性波, 下段は陽性波電位の時間的経過. $(n=6)$

Hi $200 \mu \mathrm{g}$ と cimetidine $20 \mu \mathrm{g}$ を併用した際, Hi によるVPM 陰性波の波高減少は軽度に抑 制されたが, Hi 単独群との間で有意差はいずれ の測定時間においても観察されなかった。また， VPM 陽性波は, Hi 単独投与群と $\mathrm{Hi}+$ cimetidine 投与群とで極めて類似した時間経過を示 した。同様の傾向は，RFでも認められた。
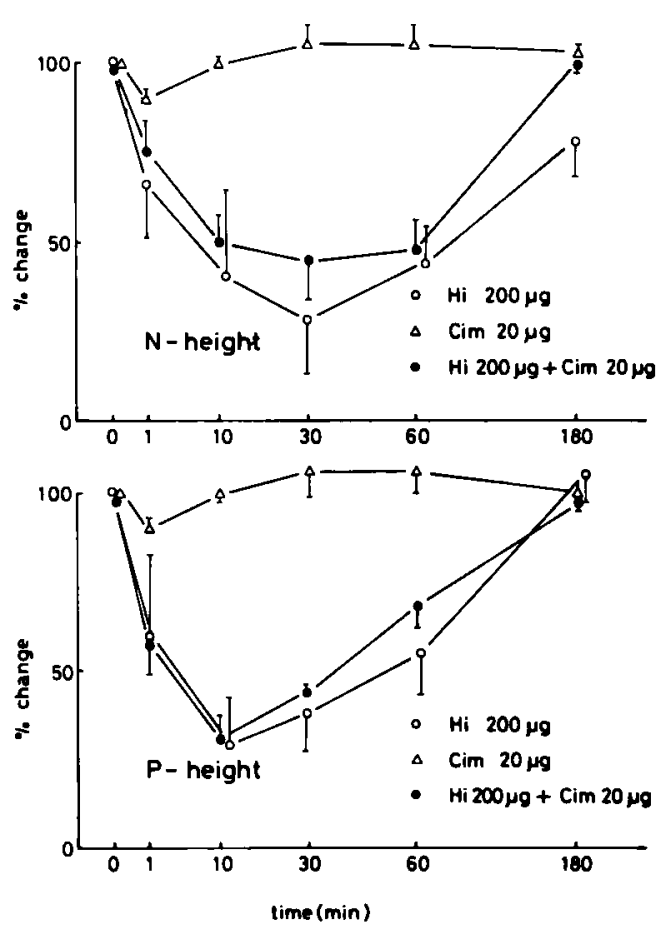

図14 ヒスタミンの RF 誘発電位抑制効果に对す る cimetidine の影響. 上段は㓌性波, 下段 は陽性波電位の時間的経過. $(n=5)$

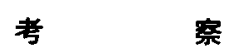

歯髄の電気刺激がほほ純粋な痛覚を誘発する 事は周知であるが8)，急性実験では種々な損傷 部位からの impulse が痛賞伝導路に input され るため，脳の特定の部位における電気信号を雪 䯣刺激と関連させて解析する事は必ずしも容易 ではない，歯髄刺激に直接関連する信号を出来 る限り純粋な形で detectするためには，慢性 電極を植えこんだ無麻醉動物で菌髄刺激を行う のが最も好ましいという考之から本赛験を企画 した。予備実験の結果から直ちに明らかになっ た事は, 大切雪に植えこんだ双極の歯䯑刺激用電極 の電極間抵抗が短期間のうちに急速に低下し，1 ～2 週で完全に短絡してしまうため刺激自体が 有効にならず，従って誘発電位も記録されなく なるという事であった．生体位実験で大切歯内 へ植え込んだ刺激電極を良好な状態で保つため 必要と思われる種々な条件について文献的検索 を行ったが、この種の報告は皆無に等しく，先 
ず基礎的な検討から開始した。 大切歯内に刺激電極を挿入した際，電極をリ 一ド線に連結しなければならないので，その直 結部位を絶縁性の高い歯科用セメントで保讙す る必要があり，その上ウサギの場合には食餌捸 取の際に大きな圧迫破砕力が大切歯に加わり， 電極挿入部にもその影響が及ぶ事が想像された。 従って，単に絶縁性の問題ばかりでなく抗破砕 カという面から検討も必要になる。また，セメ ントの硬化に長時間を要した場合には，唾液や その他の分泌物が刺激電極挿入部に付着し, 高 い極間抵抗を維持する事が困難である事も予備 実験の結果から判然としたので,この 3 点を基 準としてセメントの選択を行った。基礎実験の 結果, ユニファストが所期の目的に最も適して いる事が判ったが, ユニファストを使用する際， 先ず揮発性の有機溶媒（メタアクリル酸メチル 99\%, “ジメチルパラトルイジン1\%)に溶解し なければならないため,これらの有機溶媒が手 術創を刺激する可能性も考えられたので,この 点も考虑して数分間で乾燥する種々な非刺激性 の高絶緑性塗料を予め連結部位に塗布する事も 試みた。 その結果, ビニローゼとユニファスト の併用が絶縁性の面で最も寸ぐれている事が判 った。

刺激電極挿入部位に対する機械的損傷を可及 的少ない状態で維持するための, 今一つの手段 として硬度の低い飼料の使用が望ましかったの で,この面からも検討した，飼料会社より提供 された資料は，硬度の測定例数も少なく，且つ 統計処理を行っていない例もあったので，入手 可能なウサギ用飼料について各 100個ずつを無 差別に選び硬度を測定した。その結果, 硬度が 最も低く，且つ測定値のばらつきが最も小さか ったオリエンタル RC-4 を飼料として選んだ。

ウサギの菌髄刺激により生ずる視床 VPM 核 及び RFで記録される誘発電位は, 最初陰性方 向にふれる電位に続いて次に陽性方向にふれる 2 相性の電位が記録される事がわかった。柳田 ら11はサルを用いた実験で下顎犬歯の歯骾を刺 激した際，視床 $\mathrm{CM}$ 核及び RF で記録される 誘発電位は, 最初速い陰性方向にふれる電位に 続いて， 2 相性あるいは 3 相性の電位変動が記

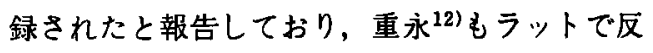
对側及び同側の歯髄電気刺激により，潜時 4 $6 \mathrm{msec}$ の陰一陽 2 相性の誘発電位が VPM ら記録されたことを報告している。本実験でも VPM から得られた誘発電位の潜時（陰性波） は反対側刺激の場合 $5.3 \pm 0.3 \mathrm{msec}$, 同側刺激

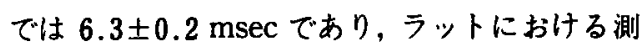
定值5)と近似した值を示した。

また，重永 ${ }^{(2)}$ はラットを用いた急性の歯涟刺 激実験で, 反対側及び同側の歯㖪を電気刺激し て,VPM で記録される誘発電位の分布を調へ た結果，歯髄刺激後の求心性インパルスは両側 性にVPMに投射するが，同側刺激により反応 する範囲は, 反対側刺激に反応する範囲に比へ 限局している事を見出している，本実験でも一 側の歯㗙刺激後, 両側の VPM で誘発電位が記 録されているが，反対側及び同側の歯檤刺激に より記録された VPM の電位を比較した場合(表 3 ), 反対側刺激で得られた電位の潜時は常に同 側刺激で得られた電位よりも短く，且つ大きい 電位が記録されている。ウサギの場合でも第 2 neuron の軸索は大部分反対側に交叉し, 三叉 神経視床路となって視床に達するものと考えら れる.

次にVPM およびRFで記録される誘発電位 を比較すると, RF 電位と VPM 電位の波形は 極めて類似しており，また電位自体の大きさに も殆んど差がなかった。この事は，上䅡神経の impulse を伝える三叉神経視床路が脳幹の内側 絨带を通過する際に側枝を出して RFに入る経 路13)は必らずしも複雑な synapse をもたない事 を示唆している．事実，歯䯚刺激後 RFで記録 される電位が $3 \mathrm{msec} の$ 潜時で出現した例があ った事，および antidromicに RF を刺激した 場合に歯骵で記録される電位の潜時が $1.8 \sim 11.5$ msec であった事より， Lovick ら`は歯䯑道よ クの求心性インパルスが monosynaptic に RF に伝えられる経路の存在する事を述へている。 非持異的に求心性の知覚信号が inputされる $\mathrm{RF}$ においても，反対側刺激の誘発電位が同側刺 激の場合よりも大きかった事は，やはり2次 neuron を伝わる impulse の多くのものが反対側 へ交叉した後視床へ向うものと考えられる。 
著者は, Ni をマウスの脳内に投与した際, 熱板 法, 電気刺激法及び化学刺激法のいずれにおい ても 2 10 $\mu \mathrm{g} /$ head と微量な $\mathrm{Hi}$ が有意な鎮 痛効果を示す事及びその機序には enkephalinergic な mechanismが関与している事を報告し た7). しかし、これらの実験方法ではHi の脳 内における作用点, 特に痛覚伝導路のいずれの 部位で作用しているのかを明確にする事はでき ない. 今回行った茵髄刺激の実験では痛覚の伝 導路の中継核として大きな生理的意義をもつ VPM と知覚性 impulse の非特異的な流入点であ る RF に電極を㨂入し, 刺激と同期して各部位 で記録される誘発電位の波形の変化から Hi 作用点を解析しようと試みた訳である。特に歯 髄刺激の際には痛賞のみが誘発されるので8), 仮性疼痛反応を指標とした前報よりもより正確 な $\mathrm{Hi} の$ 鎮痛についての情報が得られるものと 考えられた. Hi の脳室内投与は, VPM 及び RF 誘発電位を用量依存性に抑制し，その 200 $\mu \mathrm{g}$ 投与の効果は morphine $2 \mathrm{mg} / \mathrm{kg}$ 静注の効 果に匹敵し, pentazocine $5 \mathrm{mg} / \mathrm{kg}$ 静注の効果 より強かった。 morphine の中枢神経系におけ る作用点は複数であり，その機序に関しても未 だ完全には解明されていないが，脊髄後角や視 朱後腹側核にある事は既に確認されている ${ }^{14,15}$. また，中脳網様体に对しても軽度な抑制効果を 示す事が知られている ${ }^{16)}$. licking response 指標としてのウサギの歯髄刺激を行い，それに 及はす morphine の作用点を調へた Herz ら ${ }^{17)}$ の成績では, 第 4 脳室底に作用点がある事が指 摘されている。 また，視床に対する morphine の抑制効果は，視床に对する直接作用よりは黒 質ないし尾状核から視床正中核にいたる生理的 抑制経路の增強による間接的な抑制である事も 報告されている18).これらの部位における $\mathrm{Hi}$ 含量はいすれれも高い19). morphine の鎮痛機序 と細内の化学伝達物質に関する研究も非常に多 数発表されているが, Hi との関係については 殆んど知られていない.しかし, morphine の 作用が enkephalines を始めとする種々な鎮痛 性 peptides と同様に，ほ汪 pure な antagonist と考えられている naloxone によって拮抗

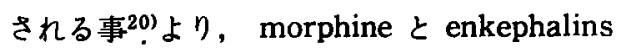

は同じ receptor に作用しているものと考えら れている. Hi の鎮痛効果が morphine を始め 種々な opioid peptides の作用に拮抗するnaloxone によって拮抗され, leucine-enkephalin によって增強される事を著者は既に報告してい $ろ^{7}$. 視床腹内側核及び中脳網様体に对する $\mathrm{Hi}$ の抑制効果発現には, morphine と類似した機 序が関与している可能性は立分あると考えられ る.

Hi の VPM およU゙ RF 誘発電位に対する抑 制効果は, 典型的な $\mathrm{H}_{1}$ blocker である pyrilamineの共存下に著明に減弱したが, $\mathrm{H}_{2}$ blocker である cimetidine は殆んど影響しなかった。 このような $\mathrm{Hi} と 2$ 種類の $\mathrm{Hi}$ 拮抗薬との拮抗 関係は, 前報の結果と一致した ${ }^{7)} . \mathrm{H}_{1}$ blockers の経口投与後中枢神経系に对する種々な抑制及 び興奮症状が発現する事は周知であるが21), cimetidine 投与後にも mental confusion ${ }^{22)}$ 证 sual hallucination が惹起される事が報告23) れている. cimetidine $の$ binding sites が中脳, 皮質及び海馬などに存在する事は知られており24), $\mathrm{H}_{2}$ receptor が中枢神経系に存在する事は確実 である、 $\mathrm{H}_{1}$ blocker が中枢神経系に対して抑 制と興奮の相反する効果を生ずるのと同様に Hi 自身も大脳皮質 neuronに对して興奮と抑制の 二面性の効果を発揮する事が知られている25). $\mathrm{H}_{1}$ blocker は, Hi のこの二面的作用のいずれ に对しても拮抗する25). Hi の脳室内投与後観 察される種々な症状の出現機序には, $\mathrm{ACh}$, dopamine 及び noradrenaline が関与する可能性 が報告されているが26,27)， $\mathrm{H}_{1}$ blocker はneuron level ではこれらのいずれの neurotransmitter の作用に对しても拮抗する事も知られて いる ${ }^{25)}$. morphine の鎮痛作用発現の mediator には, dopamine, noradrenaline, serotonin, glycine 及び GABA などの candidates が上っ ているが28)，Hi の鎮痛作用もこれらの mediatorを介して複数の機序で発現している可能性 は充分考えられる，Hı blocker が Hi の誘発電 位抑制効果に非常に強い拮抗を示したのは， $\mathrm{Hi}$ のみならずこれらの化学伝達物質に对する非特 異的な拮抗作用をもつためと考えられる。 cimetidine は $\mathrm{H}_{1}$ blockerに比較して Hiにより特 
異的に拮抗し, 他の化学伝達物質の生理作用に は殆んど拮抗しない事が知られている29). pyrilamine が拮抗し, cimetidine が拮抗し得なか った理由は, 単なる $\mathrm{H}_{1}$ と $\mathrm{H}_{2}$ receptorの関与 の差のみではなかったものと考える方がより適 切であろう。

\section{結論}

純粋な痛覚を誘発すると考えられている歯䯣 の電気刺激によって記録される視床 VPM及び $\mathrm{RF}$ の誘発電位に対し, $\mathrm{Hi}$ の側脳室内投与が 如何なる効果を及ほすのかについて，ウサギを 用いて検討した。

（1）先ず基礎的な検討として，市眅きれてい る数種の歯科用セメントについて電気的絶縁性, 硬化時間, 抗破碎力等について検討した結果, ユニファストが最もすぐれており，特にユニフ アスト使用前にビニール樹脂塗料を予め塗布し ておけば長期間にわたり刺激電極間の抵抗を高 抵抗に維持できる事が判った。

（2）ウサギ固型創料について硬度を測定した ところ,オリエンタル RC-4 が最も低い值を示 したので実験にはこれを使用した。

(3) VPM 及び RF で記録される誘発電位は, いずれも先ず陰性電位が記録され，続いて陽性 波が記録される 2 相性の反応であった.
また，いずれの部位で記録される誘発電位も， 反对側刺激の方が潜時が短く，且つ大きな電位 変動が記録された。

(4) morphine $2 \mathrm{mg} / \mathrm{kg}$ 及び pentazocine 5 $\mathrm{mg} / \mathrm{kg}$ の静注後 VPM 及び RF で記録される 誘発電位は有意に抑制された。

（5） Hi の側脳室内投与後，VPM 及び RFで 記録される誘発電位は，用量に依存して抑制さ れた. Hi $100-200 \mu \mathrm{g}$ 投与の際, その効果は 10 一30分後最大に達した。

(6) $\mathrm{Hi} 200 \mu \mathrm{g}$ 投与による VPM 及び RFの 誘発電位抑制は, pyrilamine $20 \mu \mathrm{g}$ の同時投与 により有意に拮抗されたが, cimetidine $20 \mu \mathrm{g}$ の同時投与は無効であった。

以上の成績より，ウサギ雪葡刺激による誘発 電位に対して Hi は用量一依存性の抑制効果を 示す事，及び Hi の抑制効果は $\mathrm{H}_{1}$ blocker に よって拮抗される事が判った.

\section{謝辞}

本稿を終るにあたり，御琹篤なる御指導ならじに 御校閲を賜った恩師岡山大学歯学部教授西嶋克已先 生, 岡山大学藥学部教授, 田坂賢二先生に束心より 深謝致します。

本論文の要旨は、第54回日本薬理学会総会および 第35回日本口塈科学会絵会で発表した。

\section{女 献}

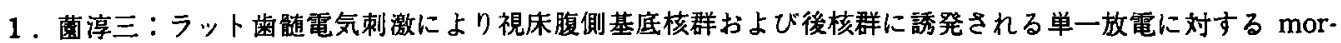
phine の影響について。 日薬理誌 68，47-65, 1972.

2. Dorian-Smith, I.: Cortical projections of thalamic neurones excited by mechanical stimulation of the face of cat. J. Physiol. 171, 339-360, 1964.

3. Lovick, T.A. and Wolstencroft, J.H.: Responses of medial reticular neurones to tooth pulp stimulation: evidence for a monosynaptic input. J. Physiol. 292, 40p-41p, 1979.

4. Shigenaga, Y., Sakai, A. and Okada, K.: Effects of tooth pulp stimulation in trigeminal nucleus caudalis and adjacent reticular formation in rat. Brain Res. 103, 400-406, 1976.

5. Halpern, B.N., Neveu, T.H. and Wilson, W.M.: The distribution and fate of radioactive histamine in the rat. J. Physiol. 147, 437-449, 1959.

6 . Sanuki, K.: The analgesic effect induced by repeated administration of histamine and histamine liberators. Jpn. J. Pharmacol. 6, 69-86, 1957.

7. 岡田郁男：ヒスタミン脳内投与による鎮痛作用発現について．岡山医会誌 94，471-485, 1982. 
8. Chin, J.H. and Domino, E.F.: Effects of morphine on brain potentials evoked by stimulation of the tooth pulp of the dog. J. Pharmacol. exp. Ther. 132, 74-90, 1961.

9. Sawyer, C.H., Everett, J.W. and Green, J.D.: The rabbit diencephalon in stereotaxic coordinates. $J$. Comp. Neurol. 101, 801-824, 1954.

10. Clark, W.G. and Cumby, H.R.: Biphasic changes in body temperature produced by intracerebroventricular injections of histamine in the rat. J. Physiol. 261, 235-253, 1976.

11. 柳田 尚, Corssen, G., Ceballos, R. and Strong, E.: Alcohol-induced hypophysectomy の除痛効果一歯髄 誘発電位に及はす影響と naloxone の拮抗作用. 麻酔 28，466-471，1979.

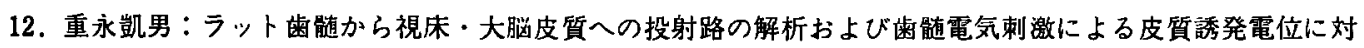
する Morphine と Barbiturate の影響について。 日薬理誌 67，22-39，1971.

13. 高木博司，松村元始：麻酥菜及び鎮痛薬の作用点一電気生理学的研究を中心として一. 基礎医学最近の進 步（薬理編）医菌薬出版，pp. 97-118，1956.

14. Fujita, S., Yasuhara, M. and Ogiu, K.: Studies on sites of action of analgesics. 1. The effect of analgesics on afferent pathways of several nerves. Jpn. J. Pharmacol. 3, 27-38, 1953.

15. Fujita, S., Yasuhara, M., Yamamoto, S. and Ogiu, K.: Studies on sites of action of analgesics. 2. The effect of analgesics on afferent. pathways of pain. Jpn. J. Pharmacol. 4, 41-51, 1954.

16. 高木博司：いたみの薬理. 神経研究の進歩 11，153-165，1967.

17. Herz, A. and Teschemacher, H. J.: Activities and sites of antinociceptive action of morphine-like analgesic and kinetics of distribution following intravenous, intracerebral and intraventricular application. Adv. Drug Res. 6, 79-119, 1971.

18. Kuromi, H., Satoh, M. and Takagi, H.: Effects of morphine and methatrimeprazine (levomepromazine) on the caudate-induced inhibition of the thalamic somatosensory evoked potential. Eur. J. Pharmacol. 24, 317-320, 1973.

19. Adams, H.H. and Hye, H.K.A.: Concentration of histamine in different parts of brain and hypophysis of cat and its modification by drugs. Br. J. Pharmacol. 28, 137-152, 1966.

20. Hughes, J., Smith, T.W., Kosterlitz, H.W., Fothergill, L.A., Morgan, B.A. and Morris, H.R.: Identification of two related pentapeptides from the brain with potent opiate agonist activity. Nature 258, 577 $-579,1975$.

21. Wyngaarden, J.B. and Seevers, M.H.: The toxic effects of antihistaminic drugs. J. Am. Med. Assoc. 145, 277-282, 1951.

22. Flind, A.C. and Rowley-Jones, D.: Mental confusion and cimetidine. Lancet 1, 379, 1979.

23. Agarwal, S.K.: Cimetidine and visual hallucinations. JAMA J. Am. Med. Asso 240, 214, 1978.

24. Burkard, W.P.: Histamine $\mathrm{H}_{2}$-receptor binding with ${ }^{3} \mathrm{H}$-cimetidine in brain. Eur. J. Pharmacol. 50 , 449-450, 1978.

25. Phillis, J.W., Tebecis, A.K. and York, D.H.: Histamine and some antihistamines: Their action on cerebral cortical neurones. Br. J. Pharmacol. 33, 426-440, 1968.

26. Nowak, J.Z. and Maślinśki, C.: Cholinergic link in the histamine-mediated increase in homovanillic acid in the rat striatum. Agents Actions 7, 27-30, 1977.

27. Subramanian, N. and Mulder, A.H.: Modulation by histamine of the efflux of radiolabelled catecholamines from rat brain slices. Eur. J. Pharmacol. 43, 143-152, 1977.

28. 高木博司：Morphine の鎮痛作用と脳内モノアミンの動態。医学のあめみ 72，617ー623，1971.

29. Douglas, W.W.: Histamine and 5-hydroxytryptamine and their antagonists. In The Pharmacological Basis of Therapeutics 6th Ed. ed. A.G. Gilman, L. Goodman, and A. Gilman, Macmillan Publishing Co., London, p. 630, 1980. 
Inhibitory effect of histamine on the potentials recorded from the VPM and RF evoked by stimulation of the tooth pulp

Ikuo OKADA

1st Department of Oral Surgery, Okayama University Dental School

(Director: Prof. K. Nishijima)

The effect of histamine (Hi) on the evoked potentials recorded from the nucleus ventralis posteromedialis thalami (VPM) and the midbrain reticular formation (RF) was studied in unanesthetized rabbits. Under pentobarbital anesthesia, the recording electrodes were implanted stereotaxically into the VPM and RF, and stimulating electrodes were inserted into the tooth pulp of both incisors of rabbits. To maintain a high electrical resistance between the stimulating electrodes, attention was paid to selecting a suitable material for protecting the soldering point. When the tooth pulp was stimulated by the repetition of square wave pulses either ipsilaterally or contralaterally, similar evoked potentials were recorded at the VPM and RF. The potentials were biphasic consisting of an initial negative deflection followed by a positive deflection. Contralateral stimulation induced larger amplitude waves with shorter latencies than those of ispilateral stimulation. Intraventricular administration of $\mathrm{Hi}$ decreased the amplitudes of evoked potentials in a dose-dependent fashion. The effect of $200 \mu \mathrm{g}$ of Hi corresponds to that produced by intravenous administration of $2 \mathrm{mg} / \mathrm{kg}$ of morphine. When the same dose of Hi was given together with $20 \mu \mathrm{g}$ of pyrilamine, the depression of the potentials was eliminated remarkably, but visible alteration was not brought about by simultaneous administration of cimetidine. 